Xiang Wu

Postgraduate student of chair for

Monumental Decorative Sculpture

Moscow State Stroganov Academy of Design and Applied Arts

e-mail: 270283983@qq.com

China

\title{
CULTURAL BACKGROUND OF CARVED STONE SCULPTURE OF ANCIENT CHINESE MAUSOLEUMS
}

Summary: The article explores the ideas, characteristic for religious mindset and philosophy of Confucianism (儒 家思想)，about spiritual immortality, filial piety and ethics, which have been firmly established in funerary culture.

Harmonic balance of Confucianism, Daoism（道教） and Buddhism brought forth the ideology and concept of immortal soul, according to which the soul does not die after person's death, and the tomb is its dwelling place. Thus, the construction of tombs gained great significance.

The author analyzes Confucian idea of 'filial piety', which, merging with ritual funeral concept, developed into a concept of 'meticulous following of funerary rituals, mourning of parents and worship of ancestors' (慎终 追远), where the main emphasis is on the organization of parents' funeral, devotion to ancestors and diligent care of their remains. Furthermore, as Ancient China was an agricultural society which was deliberately devoted to earth, it was believed that the earth is crucial for survival, and one can only rest after death if one's body is committed to earth. So, to show filial affection, properly make sacrifices, pray for protection, protect the remains and ensure eternal peaceful rest, the internment in the ground became an obligatory condition. And various funeral ar-

The concept of funeral culture refers to a person's ideas about death, combinations of funeral rituals and sacrificial rites formed under the influence of the spirit of the era, philosophical and religious consciousness, and possessing a rich cultural content. A kind of portrait of the era, it had a profound impact on the life of society and individuals. In the course of formation and development of the funeral tradition, it absorbed the religious ideas of the immortal soul and the Confucian concept of devotion to parents expressed, among other things, in 'meticulous following of funerary rituals, mourning of parents and commemoration rituals for ancestors long dead' ${ }^{1}$. All this formed into

1. Lun Yu (505-435 BC). Author: Students of Confucius / Translation and commentary: Chen Xiaofen. China Publishing House, rangements, such as marking the grave, its decoration, etc., gradually transformed into funerary plastic art. Consequently, burial in the ground allowed for the possibility and resources to form the funerary plastic art.

Ceremonial ideas presented by Mencius（孟子） have become firmly established in the concept of funeral. In a feudal society, for the convenience of government and maintaining the stability of society, etiquette, contributing to the systematization of the hierarchical order of all strata of society, as well as extreme admiration for the imperial power, became a powerful ideological weapon of the rulers. In this ideology, sculptures in the tombs of the supreme rulers - emperors and wangs - are not only guards protecting from evil, but to a greater extent they are also a symbol of imperial power. Therefore, the themes, the number and the size of the sculptures in the tombs of the emperors and wangs were of the highest importance. There is also a strict hierarchical order in the sculptures in front of the tombs of government officials of various levels. Thus, etiquette established standards and order in burial plastic art.

Keywords: mausoleum carved stone sculpture, spiritual immortality, filial piety, etiquette, luxurious funeral (厚葬).

magnificent, rich in content, ideological system with ideas of etiquette and filial piety as its core concepts.

The Confucian ideology of 'observance of funerary rituals and worship of ancestors' (慎终追远) implies following the rites of burial of parents, and rituals dedicated to the remembrance of ancestors. These are the integral part of 'filial piety' standards, which is rooted in the tradition of worship of ancestors in primitive society. The work that settled the foundation of Confucian morals was the Zhou 'Book of Etiquette' (周礼) (or The Rites of Zhou) ${ }^{2}$. It

2016., p. 32 (《论语》孔子的学生记录整理.陈晓芬译注.中华 书局.2016.01).

2. 'Book of etiquette' / Translation and notes: Xu Zhengying, Chang Peiyu. Beijing: China Publishing House, 2016, p. 62 (《周礼》徐正英, 常佩雨译注. 中华书局). 
explores the notion of 'etiquette and music' (礼乐) ${ }^{3}$ as the values, inherent in civilized state and society.

The central part of Lun Yu (论语) 'Conversations and Judgements' - the principal work of Confucianism - is occupied by the passage about 'devotion to parents and elder brothers', which is an example of ethics in Confucian society. Confucius ${ }^{4}$ said 'that one must honor his parents, respect elder brothers, be cautious, and have the skills to maintain the trust of others, to care for everyone, but make close friends only with the worthiest' ${ }^{5}$. Confucius emphasized not only the material manifestations of filial piety. Emotional sincerity was much more important for him. These particular principles served as the foundation for the formation of funerary culture and system of funeral rites.

Confucian ideology is one of the cornerstones of Ancient Chinese culture which has a profound effect on the culture of China up to the present time. In turn, the concept of 'filial piety' is the basis of Confucian ideology. The introduction of Buddhism into China during Han era ensued in the active spread of religious consciousness, still the philosophy of Confucianism remained the essential school of thought. The feudal system, which prevailed for two millennia, managed to accept and assimilate the concepts of the Buddhist teachings. Nevertheless, the new religion introduced the idea of the immortal soul, which had a significant effect on the development of funeral culture. Belief in the afterlife, or the rebirth of the soul in a parallel world, gave rise to the idea of creating the 'soul abode' where the souls of the dead could continue to exist. All this led to the introduction of luxurious funeral rites accompanied by prolonged mourning. Thus, the funeral tradition of ancient China absorbed the Confucian ideology of 'filial piety' and the religious faith in the immortality of the soul.

Emperors occupied the highest position in the Ancient Chinese feudal society; respectively, it was them who possessed the economic power, which made it possible to build the most luxurious tombs and fully materialize the idea of the 'afterlife' in the funeral ritual. The tombs of the emperors demon-

3. 'Etiquette and Music' (礼乐): 'Etiquette and Music' are called upon to cultivate moral integrity, modesty and tact in a person, to regulate the norms of behavior in various layers of society.

4. Confucius (孔夫子) (Kong Zi. 28.09.551-11.04.479 BC).

5. Lun Yu (505-435 BC). Author: Students of Confucius / Translation and commentary: Chen Xiaofen. China Publishing House, 2016., p. 22 (《论语》孔子的学生记录整理. 陈晓芬译注. 中华 书局.2016.01). strated the most perfect examples of funeral architecture and plastic art. It is here that the carved stone sculpture is born, pleading to pray for happiness, to resist evil spirits, to protect the emperor in his new life.

The ideology of 'meticulous following of funerary rituals, mourning of parents and commemoration rituals for deceased ancestors' (慎终追远) included the following:

'Luxurious funeral' (厚葬), which implied conducting a solemn funeral rite, rituals of sacrifice and long-term mourning for the deceased. Burial in the ground was the best solution to these requirements, since it implied rich funeral ceremonial, allowed for extended preservation of the remains and at the same time provided a permanent location for prayers.

Treating the dead 'after death as when they were alive' $^{6}$ (事死如生). The tradition, formed under the influence of the immortal soul ideology of Buddhism and filial piety of Confucianism, was to supply the deceased with everything he had used when he was alive. Architectural buildings, funerary items, as well as carved stone sculptures that serve as guards, servants, etc. appear in the mausoleums ${ }^{7}$.

'Prayers for wellbeing in the afterlife' (祈求冥福), demonstrating care for the soul of the deceased, and wishing him happiness and tranquility in the afterlife. They are associated with the emergence of the Feng Shui teachings, which guided the choice of a place for a tomb, the choice of sculptures designed to resist evil spirits; the formation of the tradition of visiting the grave of ancestors and sacrificing specially prepared fake money (the sacrifice performed in front of the grave was a ceremony of burning various items made of paper which imitated real-life objects such as money, houses, clothes, etc.), the tradition of donating fresh food, etc.

In the history of China, various methods of burial were used, including cremation, open-air burial, burial in water, hanging, burial in the ground, etc. Herewith, the burial in the ground the was best way to fulfill the requirements for the preservation of corpse along with the funeral inventory; and, consequently, to comply with Confucian etiquette as well.

There are three main reasons for the spread of burials in the ground:

6. Zisi. Zhong Yong. Beijing: China Publishing House, 2006., p. 12 (子思《中庸》中国图书出版社，北京，2006.10).

7. Wang Jisheng. Death is Life: Funeral Ethics and Chinese Culture. Shanghai: Baijia Publishing House, 2001, p. 96 (王计生.《事死 如生: 殡葬伦理和中国文化》上海. 百家出版社.2002.01). 
Burial in the ground allows for better preservation of the remains, albeit not for a very long period of time. Walls of coffin and a layer of soil protected them from the effects of unfavorable weather conditions and harm caused by wild animals, ensured the best possible level of preservation, and created the feeling of 'home', sheltering the deceased from wind and rain.

Burial in the ground means that a certain location must be designated for the rituals of commemoration and mourning of the deceased. Confucian morality demanded the descendants to provide the deceased with a rich life after death. This led to the appearance of various burial equipment designed to satisfy the needs of the soul in a parallel world, and to the emergence of the tradition of sacrifices on the celebration of Qingming (清明节)， a holiday of commemoration of the dead, when descendants burned paper money and household items on the ancestor's grave.

Burial in the ground is inextricably linked with the concepts of 'finding the eternal peace for the soul' (入土为安) (burial in the ground was an essential condition for the soul to find an eternal abode) and 'the unity of Heaven and man' (天人合一). These concepts reflected the affection for the land and admiration for nature in the ancient Chinese.

Thus, the ideology of funeral culture had the decisive role in the choice of burial methods. The emergence of the burial in the ground ritual paved the way for the development of burial architecture, and, as a result, for the development of carved stone sculpture in burial complexes.

\section{'Norms of morality' and luxurious funeral in Confucian ideology}

The 'norms of morality' (厚葬) meant the observance of behavioral and moral norms, strictly regulated for each of the social classes and affecting all aspects of human life.

Mencius (孟子) ${ }^{8}-a$ follower of Confucius - is one of the quintessential representatives of Confu-

8. Mencius (孟子) (372-289 BC) - one of the representatives of Confucian philosophy of the Warring States period. cian philosophy who influenced the development of the burial culture in Ancient China. During his time the concept of 'filial piety' was supplemented by the concept of 'etiquette' (礼), which included such components as the ceremonial, moral norms and hierarchy, and became one of the main pillars of the funerary culture, along with 'filial piety'. Thanks to Mencius, the concepts of 'etiquette' and 'filial piety' (孝) were firmly established in the funerary tradition of Ancient China ${ }^{9}$.

The idea of 'etiquette', actively promoted by Mencius in the funerary culture and the life of society as a whole, ideally corresponded to the aspirations of the ruling strata. From the funerary tradition point of view, it was expressed mainly in strict subordination, implying that the higher the status of the deceased, the higher was the status assigned to his tomb. This approach allowed for the systematization of the canons of funerary architecture and sculpture.

Taking into account the above, the funerary tradition, which incorporated the ideas of 'etiquette' ( 礼), 'filial piety' and belief in the immortality of the soul, served as a stimulus for the development of funerary architecture and plastic arts, created all the prerequisites for the flourishing of funerary art, and, at the same time, it contributed to the regulation of the behavior of representatives of different social classes, the formation of a standardized, systemic code for each of the strata. The highest position in the society was occupied by the emperor. The imperial tombs were distinguished by special grandeur, the funeral rites were characterized by complexity and luxury. It was the imperial tombs that revealed to us the funerary culture in its entirety and at the same time demonstrated the power of centralized power in feudal China. The carved stone sculpture, which is a symbol of social differentiation and designed to resist evil spirits as well, call out to heaven with prayers, protect the peace of the owner of the mausoleum, gradually becomes an integral part of the burial complex.

9. Fan Yong. Mencius. Beijing: China Publishing House, 2017, p. 42 (方勇译注《孟子》. 中华书局.2017.12). 


\section{REFERENCES}

1. Dong Xinlin. 2005. Archaeological research in ancient Chinese mausoleums.- Xiamen: People's Publishing House of Fujian province, p. 87 (董新林 《中国古代陵墓考古研 究》. 福建人民出版社, 2005年).

2. 'Book of Etiquette' / Translation and notes: Xu Zhengying, Chang Peiyu. Beijing: China Publishing House, 2014, p. 62 (《周礼》徐正英, 常佩雨译注. 中华书 局.2014.02).

3. Yang Kuan. 2003. A Study of the History of the Development of Tombs in Ancient China. Shanghai: People's Publishing House, p. 112 (《中国古代陵寝制度史研究》 杨宽. 上海人民出版. 2003).

4. Fan Yong. 2017. Mencius. - Beijing: China Publishing House, p. 42 (方勇译注 《孟子》.中华书局.2017.12).

5. Wang Jisheng. 2001. Death is Life: Funeral Ethics and Chinese Culture.- Shanghai: Baijia Publishing House, p. 96 (王计生. 《事死如生: 殡葬伦理和中国文化》 上海. 百家出版社. 2002.01).
6. Yang Kuan. 2010. Mausoleums in Ancient China.Nankai University Press (杨宽: 《中国古代陵墓》. 南开大学 出版社.2010.5.1).

7. 罗开平: 《中国墓葬 文化》. 海南人民出版社.1998. Luo Kaiping. Chinese Tomb Culture.- Hainan: Hainan People's Publishing House, 1998.

8. 黄忓华: 《中国佛教史》. 吉林人民出版社.2013. Huang Chanhua. History of Chinese Buddhism. Changchun: Jilin People's Publishing House, 2013.

9. Wang Luyu. 1989. Chronicle of Chinese Sculpture.Beijing: Xueyuan Publishing House, 1989 (王鲁豫: 《中国雕塑史册》. 北京, 学苑出版社.1989).

10. Feng Yulan. 2013. Brief History of Chinese Literature.-Beijing: Beijing University Press（冯友兰: 《中国哲学》. 北京: 北京大学出版社). 


\section{КУЛЬТУРНЫЕ ПРЕДПОСЫЛКИ К ФОРМИРОВАНИЮ КАМЕННОЙ РЕЗНОЙ СКУЛЬПТУРЫ В ДРЕВНЕКИТАЙСКИХ МАВЗОЛЕЯХ}

Аннотация. Аннотация: В статье исследованы характерные для религиозного сознания и философии Конфуцианства (儒家思想) идеи о бессмертности духа, сыновней почтительности, этикете, которые прочно вошли в погребальную культуру.

Гармоничное сочетание конфуцианства, даосизма (道教), буддизма породило идеологию и концепцию бессмертия души, согласно которой душа и после смерти человека не умирает, а гробница - это место её обитания. Поэтому строительству гробниц придаётся большая важность.

Автор анализирует конфуцианскую идею сыновней почтительности, которая слившись с ритуальной концепцией похорон, развилась в концепцию «тщательного соблюдения погребальных обрядов и траура по родителям, почитания предков» (慎终追远), где основной упор делается на организации похорон родителей, ревностном поклонении предкам, тщательном уходе за останками. Помимо этого, так как в древности Китай как аграрное общество отличался ярко выраженной привязанностью к земле, считалось, что человек выживает благодаря земле, а после смерти может спокойно отдохнуть, только если предать его тело земле. Поэтому для выражения сыновней любви, удобства жертвоприношений, моления о покровительстве, защиты останков усопшего, обеспечения вечного покоя умершего погребение в земле стало обязательным

Под понятием погребальной культуры подразумеваются представления человека о смерти, комплексы похоронных обрядов и ритуалов жертвоприношений, сложившиеся под влиянием духа эпохи, философского и религиозного сознания и обладающие богатым культурным содержанием. Это своеобразный портрет эпохи, оказывающий глубочайшее влияние на жизнь общества и человека. На протяжении своего становления и развития погребальный культ впитал условием. А различные погребальные мероприятия, такие как обозначение местонахождения, украшение и другие, постепенно трансформировались в погребальную пластику. Таким образом, погребение в земле обеспечило возможности и материальную базу для формирования погребальной пластики.

Идеи этикета, представляемые Мэн-цзы (孟子), прочно вошли в концепцию похорон. В феодальном обществе для удобства правления и поддержания стабильности общества этикет, способствующий систематизации иерархического порядка всех слоёв общества, а также безграничному преклонению перед императорской властью, стал мощным идеологическим оружием правителей. При такой идеологии скульптуры в гробницах верховных правителей - императоров и ванов - являются не только стражниками, защищающими от злых сил, но и в большей степени также являются символом императорской власти. Поэтому сюжеты, количество, размеры скульптур в гробницах императоров и ванов считались наивысшим разрядом. В скульптурах перед гробницами чиновников различных уровней также наблюдается строгий иерархический порядок. Таким образом, этикетом были установлены нормы и порядок в погребальной пластике.

Ключевые слова: каменная резная скульптура в мавзолее, бессмертие духа, сыновняя почтительность, этикет, «пышные» похороны (厚葬).

в себя религиозные идеи бессмертия души и конфуцианскую концепцию преданности родителям, выражаемую в том числе и в «тщательном соблюдении похоронных обрядов и траура по родителям и ритуалов поминовения давно ушедших предков» ${ }^{1}$. Таким образом сформировалась

1. «Лунь Юй» (505-435 гг. до н.э.). Автор: учени ки Конфуция / Перевод и комментарии: Чэнь Сяофэнь. Китайское книгоиздательство, 2016. С. 32 (《论语》孔子的学生记录整理.陈晓芬译注.中华书局.2016.01) 
грандиозная, богатая по своему содержанию идеологическая система, центральными понятиями которой явились идеи «этикета» и «сыновней почтительности».

Под конфуцианской идеологией «соблюдения погребальных обрядов и ритуалов почтения предков» (慎终追远) подразумевается соблюдение обрядов захоронения родителей и ритуалов, посвящённых памяти предков, являющихся составной частью «норм сыновней почтительности» и уходящих своими корнями в традиции почитания предков в первобытном обществе. Знаковым произведением, закрепившим основы конфуцианской морали, явилась «Книга этикета» эпохи Чжоу (周礼) (или «Чжоуские ритуалы») 2, раскрывающая понятие «этикета и музыки» (礼 乐) ${ }^{3}$ как ценностей, присущих цивилизованному государству и обществу.

В главном произведении конфуцианства «Лунь Юй» (论语) «Беседы и Суждения» центральное место занимает часть текста, повествующая о «преданности родителям и старшим братьям», являющая собой образец нравственности в конфуцианском обществе. Конфуций ${ }^{4}$ говорил о «необходимости почитания родителей, уважения к старшим братьям, осторожности, умения сберечь доверие окружающих, умения любить всех, но сближаться только с достойнейшими» ${ }^{5}$. Конфуций акцентировал внимание не только на материальных проявлениях сыновней почтительности. Гораздо важнее для него было соблюдение душевной искренности. Именно эти принципы и послужили фундаментом для формирования погребальной культуры и системы похоронных обрядов.

Конфуцианская идеология - один из краеугольных камней древнекитайской культуры, оказывающий глубочайшее влияние на культуру Китая вплоть до настоящего времени. В свою очередь основой конфуцианской идеологии является идея «сыновней почтительности». Проникновение в Китай в эпоху Хань философии буддизма повлекло

2. «Книга этикета» / Перевод и примечания: Сюй Чжэнъин, Чан Пэйюй. Пекин: Китайское книгоиздательство, 2014 C. 62 (《周礼》徐正英, 常佩雨译注.中华书局).

3. «Этикет и музыка» (礼乐) : «Этикет и музыка» призваны развивать в человеке моральную целостность, скромность и тактичность, регламентировать нормы поведения разных слоёв общества.

4. Конфуций (孔夫子) (Кун-цзы. 28.09.551-11.04.479 г. до н.э.).

5. «Лунь Юй» (505-435 гг. до н.э.). Автор: ученики Конфуция / Перевод и комментарии: Чэнь Сяофэнь. Китайское книгоиздательство, 2016. С. 22 (《论语》孔子的学生记录整理.陈晓芬译注.中华书局.2016.01) за собой активное распространение религиозного сознания, но основополагающим учением по-прежнему оставалась философия конфуцианства. Феодальный строй, господствующий на протяжении двух тысячелетий, сумел принять и ассимилировать основы буддийского учения. Тем не менее новая религия принесла с собой идею бессмертия души, оказавшую значительное влияние на развитие погребальной культуры. Вера в продолжение жизни, либо перерождение души в параллельном мире, породила идею создания «обители души», где души усопших могли бы продолжать своё существование. Всё это привело к появлению пышных погребальных обрядов, сопровождаемых длительным трауром. Таким образом погребальный культ Древнего Китая вобрал в себя конфуцианскую идеологию «сыновней почтительности» и религиозную веру в бессмертие души.

Высшее положение в древнекитайском феодальном обществе занимали императоры, и соответственно именно они обладали экономической мощью, позволявшей возводить наиболее роскошные гробницы, наиболее полно претворять идею «жизни после смерти» в погребальном ритуале. Гробницы императоров демонстрировали наиболее совершенные образцы погребальной архитектуры и пластики. Именно здесь и зарождается каменная резная скульптура, призванная молить о счастье, противостоять злым духам, охранять императора в его новой жизни.

Идеология «тщательного соблюдения похоронных ритуалов и траура по родителям и обрядов поминовения ушедших предков» (慎终追远) включала в себя следующее содержание:

«Пышные похороны» (厚葬), подразумевавшие проведение торжественного погребального обряда, ритуалов жертвоприношений и долгосрочный траур по усопшим. Погребение в земле лучшим образом отвечало данным требованиям, так как подразумевало богатый погребальный церемониал, позволяло на протяжении длительного времени сохранять останки усопшего и в то же время предоставляло постоянное место для молитв.

Отношение к усопшему «после смерти, как при жизни» (事死如生) ${ }^{6}$. Под влиянием буддистской идеологии бессмертия душ и конфуцианской идеологии сыновней почтительности сложилась традиция снабжения усопшего всем необходимым,

6. Зиси. Чжун Юн. Пекин: Китайское книгоиздательство, 2006. C. 12 (子思《中庸》中国图书出版社，北京，2006.10). 
чем он пользовался при жизни. В мавзолеях появляются архитектурные постройки, погребальный инвентарь, а также каменные резные скульптуры, выполняющие функции охраны, прислуги и пр ${ }^{7}$.

«Молитвы о потустороннем благополучии» (祈求冥福), демонстрирующие заботу о душе усопшего, пожелания ему счастья и спокойствия в загробном мире. С ними связывают появление учения Фэншуй, которым руководствовались при выборе места для гробницы, скульптур, призванных противостоять злым духам, формирование традиции посещения могилы предков и приношения в жертву специально подготовленных бутафорских денег (жертвоприношение представляло собой церемонию сжигания перед могилой бумажных принадлежностей, имитирующих объекты реальной жизни, включая деньги, дома, одежду и пр.), традиции принесения в дар свежей пищи и пр.

В истории Китая имели место различные способы погребения, среди которых кремация, похороны под открытым небом, погребение в воде, подвешивание, погребение в земле и пр. При этом погребение в земле наилучшим образом отвечает требованиям к сохранности тела и захороненного вместе с ним погребального инвентаря, а следовательно, и конфуцианскому этикету.

Выделяют три основные причины распространения захоронений в земле:

Захоронение в земле позволяет в лучшей степени сохранить останки, пусть и не на долгий период времени. Наличие гроба и слоя почвы уберегает их от воздействия неблагоприятных погодных условий, опасности со стороны диких зверей, обеспечивает наилучшую сохранность, создаёт ощущение "дома», укрывающего покойного от дождей и ветров.

Захоронение в земле подразумевает обозначение чёткого местоположения для совершения обрядов поминовения и оплакивания усопшего. Конфуцианская мораль требовала от потомков обеспечить усопшему богатую жизнь после смерти. Это привело к появлению разнообразного погребального инвентаря, призванного удовлетворять потребности души в параллельном мире, а также формированию традиции жертвоприношений по случаю праздника поминовения

7. Ван Цзишэн. При смерти как при жизни: похоронная этика и культура Китая. Шанхай: Издательство «Байцзя», 2001. C. 96 (王计生. 《事死如生: 殡葬伦理和中国文化》上海.百 家出版社.2002.01) усопших Цинмин (清明节), когда потомки сжигали на могиле предка бумажные деньги и предметы быта.

Захоронение в земле неразрывно связано с понятиями «обретения душой вечного покоя» (入土为安) (захоронение в земле являлось неотъемлемым условием обретения душой вечного пристанища) и «единства Неба и человека» (天人合一) 8 . В этих понятиях отразилась любовь древних китайцев к земле, преклонение перед природой.

Таким образом, идеология погребальной культуры играла решающую роль в выборе способа погребения. Появление обряда захоронения в земле открыло просторы для развития погребальной архитектуры, и, как следствие, и для развития каменной резной скульптуры в погребальных комплексах.

\section{«Нормы морали» и пышные похороны в конфуцианской идеологии}

Под «нормами морали» (厚葬) подразумевалось соблюдение поведенческих и нравственных норм, строго регламентированных для каждого из социальных классов и затрагивающих все стороны человеческой жизни.

Мэн-цзы (孟子) ${ }^{9}$ - последователь Конфуция, один из ярчайших представителей конфуцианской философии, при котором погребальная культура Древнего Китая получила своё дальнейшее развитие. При нём концепция «сыновней почтительности» была дополнена понятием «этикета» (礼)， включающим в себя такие составляющие, как церемониал, нравственные нормы, иерархия, и ставшим одним из основных столпов погребальной культуры, наряду с «сыновней почтительностью». Благодаря Мэн-цзы понятия «этикета» и «сыновней почтительности» (孝) прочно укрепляются в погребальном культе Древнего Китая ${ }^{10}$

Идея «этикета», активно продвигаемая Мэнцзы в погребальной культуре и жизни социума в целом, идеальным образом соответствовала стремлениям правящих слоёв. С точки зрения погребального культа она выразилась главным образом в строгой субординации, подразумевающей, что чем более высок статус усопшего,

8. «Единство Неба и человека» (天人合一) - философская концепция, стремление к гармоничному сосуществованию человека и неба, где человек и природа сливаются воедино и оказывают взаимное влияние друг на друга.

9. Мэн-цзы (孟子) (372-289 гг. до н.э.) - один из представителей конфуцианской философии периода Сражающихся царств.

10. Фан Юн. Мэн-цзы. Пекин: Китайское книгоиздательство, 2017. C. 42 (方勇译注《孟子》. 中华书局.2017.12) 
тем более высокий статус присваивался его гробнице. Такой подход позволил систематизировать каноны погребальной архитектуры и скульптуры.

Принимая во внимание вышеизложенное, погребальный культ, вобравший в себя идеи «этикета» (礼), «сыновней почтительности» и веру в бессмертие души, послужил стимулом к развитию погребальной архитектуры и пластики, создал все предпосылки для расцвета погребального искусства, и в то же время способствовал регламентации поведения представителей разных социальных классов, формированию стандартизированного, системного кодекса для каждого из слоёв. Высшее положение в обществе зани- мал император. Императорские гробницы отличались особой величественностью, похоронным обрядам были присущи сложность и пышность. Именно императорские гробницы явили нам погребальную культуру во всей её полноте и в то же время продемонстрировали мощь централизованной власти в феодальном Китае. Каменная резная скульптура, являющая собой символ социальной дифференциации, а также призванная оказывать противостояние злым духам, взывать с молитвами к небу, защищать покой хозяина мавзолея, постепенно становится неотъемлемым элементом погребального комплекса.

\section{БИБЛИОГРАФИЯ}

1. Дун Синьлинь. Археологические исследования в древнекитайских мавзолеях. - Сямэнь: Народное издательство пров. Фуцзянь, 2005.C. 87 (董新林 《中国古代陵墓考古研究》. 福建人 民出版社，2005年).

2. Книга этикета / Перевод и примечания: Сюй Чжэнъин, Чан Пэйюй.- Пекин: Китайское книгоиздательство, 2014.- С. 62 (《周礼》 徐正 英, 常佩雨译注.中华书局.2014.02).

3. Ян Куань. Исследование истории развития гробниц в Древнем Китае.- Шанхай: Народное издательство, 2003.- С. 112 (《中国古代陵寝制度史研究》 杨宽. 上海人民出 版社. 2003).

4. Фан Юн. Мэн-цзы. - Пекин: Китайское книгоиздательство, 2017.—C. 42 (方勇译注 《孟子》. 中华书局.2017.12.).

5. Ван Цзишэн. После смерти, как при жизни: похоронная этика и культура Китая. - Шанхай: Издательство «Байцзя», 2001.- С. 96 (王计
生. 《事死如生: 殡葬伦理和中国文化》上海. 百 家出版社. 2002.01).

6. Ян Куань. Мавзолеи в Древнем Китае.-Издательство Нанкайского университета, 2010 (杨 宽: 《中国古代陵墓》. 南开大学出版社. 2010.5.1).

7. 罗开平: 《中国墓葬文化》. 海南人民出版社. 1998. Ло Кайпин. Китайская культура гробниц. Хайнань: Народное издательство Хайнаня, 1998.

8. 黄忓华: 《中国佛教史》. 吉林人民出版社. 2013. Хуан Чаньхуа. История китайского буддизма. - Чанчунь: Цзилинское народное издательство, 2013.

9. Ван Луюй. Летопись китайской скульптуры.Пекин: Издательство Сюэюань, 1989 (王鲁豫: 《中 国雕塑史册》. 北京, 学苑出版社. 1989).

10. Фэн Юлань. Краткая история китайской философии. - Пекин: Издательство Пекинского университета, 2013 (冯友兰: 《中国哲学简史》. 北 京: 北京大学出版社). 